\title{
Bioethanol Production from Coconut Fiber using Alkaline Pretreatment and Acid Hydrolysis Method
}

\author{
Asyeni Miftahul Jannah and Faisol Asip \\ \# Department of Chemical Engineering, Faculty of Engineering, Sriwijaya University, South Sumatera 30662, Indonesia \\ E-mail: chezy_45@yahoo.co.id; faisol-asip@yahoo.com
}

\begin{abstract}
Supporting Indonesia government program to decrease fuel consumption, using renewable energy such of bioethanol is one of the best ways. This research was done in order to utilize agriculture waste (coconut fiber) as raw material to produce bioetanol. However, coconut fiber contents lignin that will inhibit conversion process of glucose into ethanol. In this research, pretreatment steps aim to release and breakdown lignin in coconut fiber. Pretreatment was conducted by using alkaline method with 3\% Sodium Hydroxide solution. Hydrolysis method was used to produce glucose by using Sulfuric Acid solution with various concentrations (1\%, $2 \%, 3 \%$, and $4 \%$ ) while in fermentation process used Saccharomyces cerevisiae with various times (5, 7, 9, and 11 days) and distillation used to get pure product of bioethanol. The results showed that higher $\mathrm{H}_{2} \mathrm{SO}_{4}$ concentration using on hydrolysis process

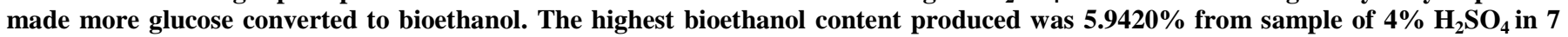
days of fermentation.
\end{abstract}

Keywords - coconut fiber; pretreatment; hydrolysis; fermentation; bioethanol.

\section{INTRODUCTION}

The government programs on energy conversion should be supported by seeking the alternative sources of renewable energy. A large number of studies regarding the utilization of lignocellulosic biomass as a feedstock for producing bioethanol has been carried out ([1], [2], [3]). The coconut fiber is one of the abundant lignocelullosic waste materials, contains the cellulose and hemicellulose that potentially to be further utilized to bioethanol. In term of chemical composition, the coconut fiber pre-dominantly contains the cellulose (43.4\%), hemicellulose (19.9\%) and lignin (45.8\%) [4].The coconut fibers used in this research were taken from agricultural waste from Prabumulih, a small city in South Sumatera. After coconuts harvest, most of farmers sold the coconuts without the fibers so the coconuts peeled and the fibers were discarded as waste. Some farmers usually burned the coconut fibers in their field to avoid the smell that produced from piles of coconut fibers which left without any benefit. Besides supporting government program on energy conversion, the using of coconut fiber as raw material of bioethanol production also helped the farmers to eliminate and reduce the agriculture waste that always produced as harvest excess and in same way to get added value of coconut fiber compared only as agricultural waste.
The production of bioethanol involves different process steps including biomass pre-treatment, hydrolysis, fermentation and product recovery. Biomass pre-treatment is one of the most crucial and expensive process steps that has been widely discovered [5]. The pretreatment process is important for increasing the enzymatic digestibility of lignocellulosic materials[6]. The purpose of the pretreatment is to remove lignin and hemicellulose, avoid the degradation or loss of carbohydrate, avoid the formation of byproducts inhibitory to the subsequent hydrolysis and fermentation processes; and be cost-effective.

Alkaline pretreatment method is one of pretreatment processes which is preferable due to the lower temperature and pressure involved [7]. In addition, alkaline pre-treatment spent low cost compared to acid pretreatment. This study aimed to get bioethanol from coconut fiber using alkaline pretreatment to release lignin content and acid hydrolysis and fermentation to produce bioethanol from cellulose by using Saccharomyces cerevisiae.

\section{MATERIAL AND METHODS}

\section{A. Raw Material}

The dried coconut fiber was collected from Prabumulih, South Sumatera province. The first step of processing coconut fiber was drying it until well dried. Coconut fiber 
was dried under sunlight then milled and sieved with fraction 80-mesh screen and stored in a sealed plastic bag at room temperature.

\section{B. Alkaline Pretreatment}

The dried coconut fiber $(30 \mathrm{~g})$ was treated with $3 \%$ sodium hydroxide solution $(\mathrm{NaOH})(\mathrm{w} / \mathrm{v})$. Treatments were performed in autoclave at $121^{\circ} \mathrm{C}$ for 90 minutes. The pretreated material was washed with aqueous until the filtrate registered a neutral $\mathrm{pH}(\mathrm{pH} 7)$. Then pretreated solids were dried in the oven at $85^{\circ} \mathrm{C}$ for 4 hours until dried. Samples were stored in desiccators until their use. This process aimed to break the lignin bonding and did not obstruct the hydrolysis process.

\section{Acid Hydrolysis}

The dried pretreated samples was dilutd with $500 \mathrm{~mL}$ aqueous into Erlenmeyer and adjusted $300 \mathrm{~mL}$ of sulfuric acid solution at concentration of $1 \%, 2 \%, 3 \%$ and $4 \%(\mathrm{v} / \mathrm{w})$. Samples performed in the autoclave at $121^{\circ} \mathrm{C}$ for 2 hours. Reaction of slurry with acid solution will be accelerated by heating additional.

\section{Fermentation}

The slurry was cooled and $\mathrm{pH}$ adjusted to $\mathrm{pH}$ of 4.5 until 5 using sodium hydroxide. 0.03 (g/L) Saccharomyces cerevisiae were added into slurry and stirred at $150 \mathrm{rpm}$ until homogeneous. Fermentation process was done with various times (5, 7, 9, and 11 days). The slurry was filtered and purified by distillation.

\section{ANALYSIS}

The lignin content in the coconut fiber as a raw material was determined before pretreated and after pretreated for each steps. It was analysis by using extraction $\mathrm{ZnCl}_{2}$ $\mathrm{CH}_{3} \mathrm{COOH}$ blending method. The $70 \%(\mathrm{v} / \mathrm{v})$ of $\mathrm{CH}_{3} \mathrm{COOH}$ contains $35 \%$ (w/v) of $\mathrm{ZnCl}_{2}$ was blended. $20 \mathrm{~g}$ of driedoven sample was added to the blend and heated to the water bath during 1 hour at the boiling point $100^{\circ} \mathrm{C}$. Then, the sample was cooled, placed into Buchner funnel, squeezed and washed with $\mathrm{CH}_{3} \mathrm{COOH}-\mathrm{H}_{2} \mathrm{O}$ blend. Distillate water (50 $\mathrm{mL}$ ) was added to the remaining solution for precipitation and coagulation of residual lignin. Then the solution was filtered, washed with distillate water and the product was dried at $40^{\circ} \mathrm{C}$. Mass of lignin was determined by difference between the mass of empty filter and filter with lignin after extraction. The glucose that produce after hydrolysis was determined by using titration with adding Luff-Schoorl solution (SNI-01-2891-1992) and the bioethanol determined using GC-2010 Plus Series Gas Chromatography.

\section{RESULT AND DISCUSSION}

The lignin content for coconut fiber before pretreatment was $37.96 \%$ and the lignin content after alkaline pretreatment was $9.69 \%$. The lignin content in the sample was decreased by using $3 \%(\mathrm{w} / \mathrm{v})$ sodium hydroxide pretreatment. It indicated that the sodium hydroxide concentration used in the pretreatment was able to eliminate lignin molecules that protected cellulose. It was found that the use of dilute sodium hydroxide treatment of lignocellulosic materials lead the swelling, the increasing of internal surface area, the decreasing in the degree of polymerization, the decreasing in crystallinity, the separating of structural linkages between lignin and carbohydrates, and the disrupting of the lignin structure [8].

After pretreatment process, the dried samples were hydrolyzed using sulfuric acid solution with various concentrations. Figure 1 below showed amount of glucose that produced in hydrolysis process. The highest glucose concentration was showed by sample treated with $4 \%$ sulfuric acid (v/w). Acid catalyst can accelerate decomposition reaction of cellulose to glucose in raw material. The more catalyst was used, the greater amount of glucose formed.

The principle of hydrolysis process was the polymer chains terminated into glucose monomers. In this study used acid hydrolysis process to help the starch polymer chain termination. The more catalysts are used, the faster hydrolysis reaction occurred, within certain time amount of cellulose converted into glucose will increase [9].

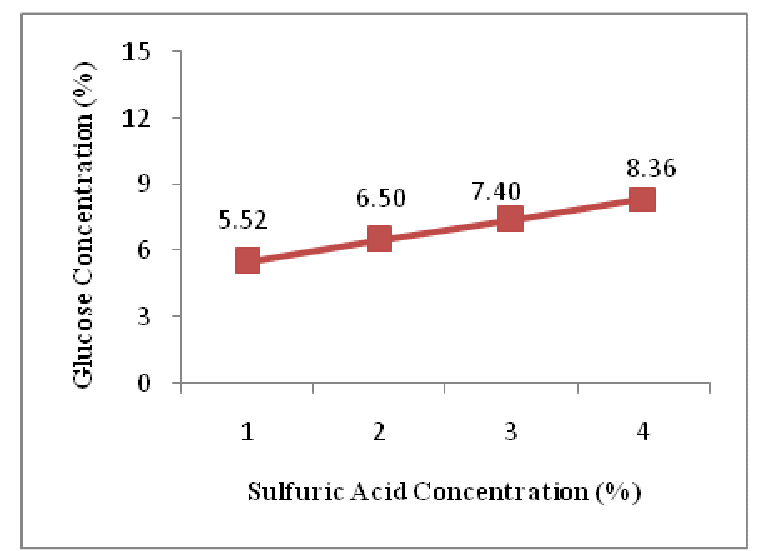

Fig. 1 Glucose concentrations after acid hydrolysis process

Fermentation process was done in various times which were 5, 7, 9 and 11 days. In those terms, maximum ethanol produced by sample that treated with $4 \%$ sulfuric acid in 7 days of fermentation. The concentration of ethanol was present in figure 2.

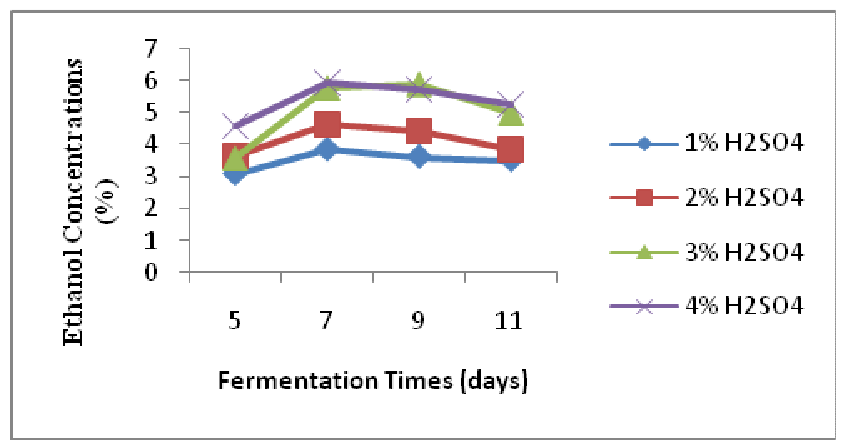

Fig. 2 Ethanol concentrations after fermentation process

It showed that effectively fermentation time was in 7 days fermentation because in this time yeast worked optimally. Starting from 5 days fermentation to 7 days fermentation amount of ethanol productions increased. In this time yeast was in exponential phase and the optimal reaction time of 
fermentations were in 7 days where yeast was in stationary phase. Figure 2 also explanained that after 7 days fermentation the amount of ethanol production went to decreased becaused yeast worked not optimally and went to the death phase. The ethanol yield reached maximum in the sample treated with $4 \%$ sulfuric acid with 7 days fermentation time which was at concentration of $5.9420 \%$.

\section{CONCLUSIONS}

Using of 3\% Sodium Hydroxide was applied in the pretreatment of coconut fiber followed by acid hydrolysis and fermentation using Saccharomyces cerevisiae. These pretreatments aimed to remove lignin from lignocelluloses. After pretreatment the lignin content decreased $74.47 \%$, it showed the alkaline pretreatment method removed lignin effectively. The using of sulfuric acid the hydrolysis process gave big impact for the ethanol yield. The more sulfuric acid reacted with slurry of coconut fiber the highest ethanol yield could be produced. The highest ethanol concentration was $5.9420 \%$ which reached by sample treated $4 \%$ sulfuric acid and fermented for 7 days.

\section{ACKNOWLEDGMENT}

The authors are grateful to University of Sriwijaya for funding this project by Research of Technology Science and Art No. 216/UN9.3.1/LT/2015.

\section{REFERENCES}

[1] Chen, H., Ben-Li, P., Ching, T., \& Wen, S. 2010. Pretreatment Efficiency And Structural Characterization Of Rice Straw By An Integrated Process of Dilute-Acid and Steam Explosion for Bioethanol Production. Bioresource Technology, 1-9.

[2] Xavier, A., Correia, M., Pereira, S., \& Eutuguin, D. 2010. Secondgeneration Bioethanol from Eucalypt Sulphite Spent Liquor. Bioresource Technology, 2755-2761.

[3] Karimi, K., Emtiazi, G., \& Taherzadeh, M. J. 2006. Ethanol production from dilute-acid pretreated rice straw by simultaneous saccharification and fermentation with Mucor indicus, Rhizopus oryzae, and Saccharomyces cerevisiae. Enzyme and Microbial Technology , 40:138-144.

[4] Sukadarti. S., Kholisoh, D.S., Prasetyo, H., Santoso, P.W., dan Mursini, T. 2010. Produksi Gula Reduksi dari Sabut Kelapa Menggunakan Jamur Trichoderma reesei. Teknik Kimia. UPN Yogyakarta.

[5] Rabelo, S., Filho, R., \& Costa, A. 2009. Lime Pretreatment Of Sugarcane Bagasse For bioethanol Production. Appl. Biochem Biotechno, 153:139-50.

[6] Chang, K., Thitikorn-amorn, J., Hsieh, J., \& Ou, B. 2011. Enhanced Enzymatic Conversion with Freeze Pretreatment of Rice straw. Biomass and bioenergy, 35: 90-95.

[7] Zhang B, Shahbazi A, Wang L. 2010. Alkali Pretreatment And Enzymatic Hydrolysis Of Cattails From Constructed Wetlands. Am J Eng Appl Sci 3 :328-32.

[8] Sun, Y., \& Cheng, J. 2002. Hydrolysis of lignocellulosic materials for ethanol production: a review. Bioresource Technology(83: 1-11) 83: $1-11$

[9] Kriswiyanti, E. dan P.A., Andik. 2006. Pengaruh Konsentrasi Asam Terhadap Hidrolisis Pati Pisang. Jurnal Teknik Kimia, UNS. Surakarta. 